\title{
Mega-Events and Housing Costs: Raising the Rent while Raising the Roof?
}

\author{
By \\ Dennis Coates \\ and \\ Victor A. Matheson \\ January 2009 \\ COLLEGE OF THE HOLY CROSS, DEPARTMENT OF ECONOMICS \\ FACULTY RESEARCH SERIES, PAPER NO. 09-03*

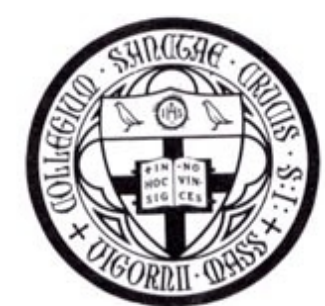 \\ Department of Economics \\ College of the Holy Cross \\ Box 45A \\ Worcester, Massachusetts 01610 \\ (508) 793-3362 (phone) \\ (508) 793-3708 (fax)
}

http://www.holycross.edu/departments/economics/website

*All papers in the Holy Cross Working Paper Series should be considered draft versions subject to future revision. Comments and suggestions are welcome. 


\title{
Mega-Events and Housing Costs: Raising the Rent while Raising the Roof?
}

\author{
By \\ Dennis Coates ${ }^{\dagger}$ \\ University of Maryland, Baltimore County \\ and \\ Victor A. Matheson ${ }^{\dagger \dagger}$ \\ College of the Holy Cross
}

January 2009

\begin{abstract}
This paper examines the relationship between hosting mega-events such as the Super Bowl, Olympics, and World Cup and rental housing prices in host cities. If mega-events are amenities for local residents, then rental housing prices can serve as a proxy for estimating residents' willingness to pay for these amenities. An analysis of rental prices in a panel of American cities from 1993-2005 fails to find a consistent impact of mega-events on rental prices. When controls are placed on the regression models to account for nationwide annual fluctuations in rental prices, mega-events generally exhibit little impact on rental prices in cities as a whole and are as likely to reduce rental prices as increase them. Somewhat stronger evidence exists, however, that mega-events affect rental prices outside of the center city in a fundamentally different manner than in the city core.
\end{abstract}

JEL Classification Codes: L83, O18, R53

Keywords: sports, stadiums, franchises, impact analysis, mega-event, housing

Department of Economics, University of Maryland, Baltimore County, 1000 Hilltop Circle, Baltimore, MD 21250, (410) 455-3243 (office), coates@umbc.edu

${ }^{\dagger}$ Department of Economics, Box 157A, College of the Holy Cross, Worcester, MA 01610-2395, 508-793-2649 (phone), 508-793-3708 (fax), vmatheso@holycross.edu 


\section{Introduction}

Large sporting events such as the Olympics, World Cup, and league championships like the Super Bowl are highly sought after by cities, states, and countries. Indeed the competition among governments to host these "mega-events" can be as vigorous as the competition on the playing fields themselves. These premier events, however, often carry very high price tags. The governing bodies of sports such as the International Olympic Committee (IOC), the Fédération Internationale de Football Association (FIFA), or the National Football League (NFL) insist on state-of-the-art playing facilities and first-class accommodations for athletes, officials, and spectators.

For example, in order to host the 2002 FIFA World Cup, South Korea built ten new stadiums at a cost of nearly $\$ 2$ billion, and Japan constructed seven new stadiums and refurbished three others at a cost of at least $\$ 4$ billion. The total investment for new infrastructure in Japan for the event was estimated by some analysts at more than 750 billion yen (\$5.6 billion) (Baade and Matheson, 2004). In the United States, the NFL typically awards the Super Bowl to cities that have recently completed stadium construction or major refurbishments. For example, seven of the last ten Super Bowls have been held in stadiums less than 10 years old, and the 2011 and 2012 Super Bowls have been awarded to Dallas-Fort Worth and Indianapolis, respectively, due to new stadiums either recently opening or soon due to debut in these cities. Of course, the best example of massive spending on a mega-event comes from Beijing. The Chinese government reportedly spent in excess of $\$ 40$ billion in conjunction with the 2008 Summer Olympics (Berlin, 2008; Baker 2008). 
In addition, as these events attract worldwide attention, they also become targets for terrorist activities, as witnessed at the Summer Olympics in Munich in 1972 and in Atlanta in 1996, and therefore security requirements are also very high. Greece reportedly spent $\$ 1.5$ billion on security alone for the 2004 Summer Olympics (Meeks, 2004), and security restrictions in Beijing in 2008 "appear to have virtually eliminated any boost in tourism from the Olympics." (Baker, 2008) Thus, cities incur not only large capital expenses in conjunction with hosting large sporting events, but the operating costs can also be astronomical.

Local, state, and national governments typically justify their spending on sporting events on three grounds. First, they contend that these events attract athletes, spectators, officials, and media which increases revenue for accommodations, restaurants, and retail establishments. For example, the NFL estimates that the average economic impact of the Super Bowl on the host city is $\$ 300$ to $\$ 400$ million (Arizona Super Bowl Host Committee, 2008). Multi-day events such as the Summer or Winter Olympics or the World Cup can generate economic impact estimates well into the billions of dollars.

Second, the sports boosters suggest that sporting events serve to publicize host cities to prospective tourists and future visitors. In justifying the $\$ 7.7$ million budgeted to sports tourism, the Hawaii Tourism Authority states, "The positive media and publicity generated from national and international TV/ media coverage promotes Hawaii as a desirable sports venue and an attractive visitor destination." (Hawaii Tourism Authority, 2007,pg. 22) 
Third, these events may improve the quality of life of local residents by allowing them opportunities to watch major sporting events. The excitement surrounding these major events may make certain cities particularly desirable places to live or work.

Sports economists have frequently dealt with similar claims of economic benefits from sports. The question of whether sporting events directly lead to increases in economic activity has been the most widely explored in the literature. As opposed to economic impact studies commissioned by the sports teams or leagues, independent economists examining an area's economy before, during, and after major sporting events tend to find little or no economic impact from hosting major events.

In general, while league-sponsored estimates may do a credible job in determining the economic activity that occurs as a result of a mega-event, they usually do a poor job of accounting for economic activity that is displaced by these games and often apply incorrect multipliers. For these reasons, numerous studies have looked back at the actual performance of economies that have hosted mega-events and have compared the observed economic performance of host cities to that predicted in ex ante studies. Ex post analyses such as Porter (1999), Baade and Matheson (2001; 2004; 2006), Coates and Humphreys (2002), Coates (2006), Coates and Depken (2006), Hagn and Maennig (2007a; 2007b), Jasmand and Maennig (2007), and Baade, Baumann, and Matheson (2008), similarly uncover little relationship between hosting major sporting events and real economic variables such as employment, personal income, personal income per capita, and taxable sales.

Sports backers also suggest that sporting events serve to publicize host cities to prospective tourists. As noted by Matheson (2008), "Sports fans may enjoy their visit to 
the city and return later raising future tourist revenues for the area. Corporate visitors, it is claimed, may relocate manufacturing facilities and company headquarters to the city. Television viewers might decide to take a trip to the host city at some time in the future based on what they see during the broadcast of the mega-event. Finally, hosting a major event might raise perceptions of the city so that it becomes a "major league" or "world class" city and travel destination. All of these claims are potentially true although little empirical research has conclusively demonstrated any long-run connections between hosting mega-events and future tourism demand, and there are not even any anecdotal examples of companies moving corporate operations to a city based on the hosting of a sporting event."

Empirically, the 1988 Winter Olympics did increase the worldwide name recognition of Calgary, but the effect was short-lived (Ritchie and Smith,1991). Similarly, the aftermath of the 1994 Winter Olympic Games did not bring a sustained boost in tourism to Lillehammer, but instead, $40 \%$ of the full-service hotels in the town soon went bankrupt (Tieglund, 1999).

Furthermore, while mega-events clearly shine the limelight on host cities, not all the publicity generated is necessarily positive. For example, the riots following Detroit's National Basketball Association championships in the early 1990s did little to improve the city's status, and the bribery scandal that surrounded award of the 2002 Winter Olympics to Salt Lake City similarly tarnished that city’s reputation. Likewise, the international images of Munich and Atlanta were marred by the terrorist events that occurred during their respective Summer Olympic Games. 
Finally, the sports boosters note that these events improve the quality of life of local residents by allowing them opportunities to watch major sporting events, and it is this claim that will be the focus of this paper. Again, it is clear that sports do bring some intangible benefits to local residents. As Rudy Perpich, the former governor of Minnesota, once quipped, "Without professional sports, Minneapolis would just be a cold Omaha." (Baumann, Matheson, and Muroi, 2009) Of course, measuring these benefits is a difficult task, and academic studies do not come to a uniform conclusion on the subject. Contingent valuation studies of professional sports franchises (Johnson, Groothius, and Whitehead, 2001; Johnson, Mondello, and Whitehead; 2006), stadiums and arenas (Groothius, Johnson, and Whitehead, 2004), and mega-events (Atkinson, et al., 2008; Walton, Longo, and Dawson, 2008) identify a willingness to pay for sports teams and events that is not simply captured in ticket sales. These identified intangible benefits, however, are generally smaller than the taxpayer contributions to stadium construction or event subsidization. Maennig (2007) analyzes the 2006 World Cup in Germany and similarly concludes that claims of "increased turnover in the retail trade, overnight accommodation, receipts from tourism and effects on employment [are] mostly of little value and may even be incorrect. Of more significance, however, are other (measurable) effects such as the novelty effect of the stadiums, the improved image for Germany and the feel good effect for the population.” (Maennig, 2007, p. 1)

$\mathrm{Tu}$ (2005) estimated the impact of FedEx Field in Maryland, just outside of Washington, DC, on the property values around that venue using actual sale prices before and after construction in a differences-in-differences analysis. Ahlfeldt and Maennig (2007) evaluate the impact of three venues in Berlin on property values using a hedonic 
price model. Feng and Humphreys (2008) use spatial econometrics to assess the effects of venues in Columbus, Ohio on property values in that city. The common link among these papers is that they focus on properties in a single community and proximity to specific sports facilities. In each of them, there is evidence that properties closer to the sports venues are priced differently than otherwise identical venues farther from the stadium or arena. These studies, therefore, estimate the extent of local externalities or spillovers from sports facilities in the same way that one might consider the spillovers from proximity to a noxious facility, like a prison or hazardous waste treatment facility (Boyle and Kiel, 2001). Moreover, the conclusions are quite consistent with the argument against stadium and arena subsidies that stadiums do not generate large areawide benefits but rather induce concentrated benefits in a small area close to the venue. Carlino and Coulson (2004) employ a different tactic in determining that NFL franchises have a positive impact on host cities. In particular, their goal is to assess the benefits of the presence of a sports franchise in the metropolitan area, benefits that are supposed to reach all neighborhoods in the area, regardless of distance to the home field of the team. They find that housing rental prices are higher in cities with NFL teams and hypothesize that residents are willing to pay higher rents for the opportunity to live in a city with an amenity like an NFL franchise. Of course, cities with professional teams are generally larger metropolitan areas, which offer many other cultural attractions for which renters would also be willing to pay a premium. Indeed, Coates, Humphreys and Zimbalist (2006) find that Carlino and Coulson's results are highly dependent on model specification; however, other studies have confirmed a relationship between housing prices and sporting venues. Coates and Gearhart (2008) used the same approach as 
Carlino and Coulson to study the relationship between residential rental values and hosting NASCAR races. They likened the one-off nature of a major event like the Daytona 500 to a mega-event, like hosting the Super Bowl or a World Cup.

This paper examines whether hosting mega-events has a discernable effect on housing rental prices in host cities. In this paper we focus on three unquestioned megaevents, the Super Bowl, the Olympics, and the World Cup. The Super Bowl is, of course, played every year with the location varying from year to year. Between 1993, when our data begins, and 2005, the last year of our data, both the Olympics and the World Cup have been held in the United States. The World Cup round robin games were played at several sites around the country, and the Summer and Winter Olympics were hosted by Atlanta and Salt Lake City, respectively.

The results of our analysis indicate that rental values are generally affected by hosting these mega-events. We estimate our model on three different subsamples, and in each case we reject the null hypothesis that the mega-event variables all have a coefficient of zero. However, the results also indicate that the primary action, in terms of individually statistically significant effects, is in hosting the Olympics and, especially, the World Cup.

\section{Model Presentation}

We estimate a hedonic model of the rental price of housing. Among the attributes of the rental units that are priced in our model are characteristics of the unit, such as its age or the number of bedrooms, and characteristics of its immediate surroundings, like heavy traffic or garbage in the neighborhood streets. The coefficient on each 
characteristic (either an attribute or surrounding) is interpreted as the marginal value, or equilibrium price, of one unit of that characteristic. A significant coefficient means the presence of the associated characteristic shifts the demand or the supply for housing, either increasing or decreasing the equilibrium price of a rental.

In our analysis, the characteristic whose value is of interest, in our case whether or not a city hosts the Super Bowl, Olympic Games, or World Cup soccer matches in a given year, will have equal impact on rents everywhere in the community. Carlino and Coulson (2004) followed this approach to assess the social benefits to a community of hosting a professional football franchise. Coates and Gearhart (2008) used this method to determine if hosting NASCAR events affected rents.

We examine the rent data for evidence that hosting any of these mega-events translates into changes in the rental rate. If people receive non-pecuniary benefits from hosting an event, they may express it indirectly through an increased demand for housing in the area. This increased demand bids up the price of housing, which consequently increases rental values. One possible non-pecuniary benefit received from hosting the Super Bowl, for example, is the enhanced sense of community pride attributable to the national and world-wide exposure of the city that comes with the Super Bowl. This effect is the same for all of the people living in the area, regardless of their proximity to the stadium where the game takes place, and is what this paper attempts to measure.

This paper will follow Carlino and Coulson (2004) and Coates and Gearhart (2008), using essentially the same housing data, and many of the same control variables. However, unlike Carlino and Coulson, this paper addresses the impact of specific events. Of course, they could not evaluate the effect of individual NFL games on rents because 
the rental data is annual and each franchise has 8 or more home games. Furthermore, NFL teams only infrequently leave cities or enter new markets. This makes it difficult to determine whether the high rental rates commonly found in NFL cities are a result of the franchise itself or other attributes of the area. By contrast, only one Super Bowl is played annually, and its location changes from year to year. The Olympics and World Cup, while encompassing several days of events, are also only in town once. Moreover, many cities host NFL teams that did not and never will host the Super Bowl, Olympics, or World Cup. We estimate the hedonic rent model on three sets of data: 1) the full sample of SMSAs used in Coates and Gearhart (2008), 2) all cities that were home to an NFL, NBA (basketball), MLB (baseball), or NHL (hockey) franchise at some time during our time frame for which the rental data exist and 3) the subset of cities that actually hosted a Super Bowl.

The dependent variable in the models will be the natural log of real rent, with 1993 as the base year. Nominal rents are converted to real rents using the CPI inflation calculator available at the Bureau of Labor Statistics website (http://data.bls.gov/cgibin/cpicalc.pl). The model is estimated with SMSA-specific fixed effects. Also, interactions between the time variable and the SMSA dummy variables are included to allow for SMSA specific time trends. The general model is as follows:

$$
\text { lndrent } \mathrm{ijt}_{\mathrm{jt}}=\alpha \mathrm{A}_{\mathrm{jt}}+\beta \mathrm{H}_{\mathrm{ijt}}+\sum \delta_{\mathrm{j}} \mathrm{SMSA}_{\mathrm{jt}}+\sum \gamma_{\mathrm{j}}\left(\mathrm{SMSA}^{*} \mathrm{time}_{\mathrm{jt}}+\sum \lambda_{\mathrm{y}} \mathrm{year}_{\mathrm{yt}}+\varepsilon_{\mathrm{ijt}},\right.
$$

where $A_{j t}$ is the Super Bowl or other mega-event host variable (or variables), $\mathrm{H}_{\mathrm{ijt}}$ are housing unit characteristics, $\alpha$ is the parameter (or parameters) of interest measuring the 
implicit rental price of hosting the Super Bowl and the other mega-events, and $\beta$ is a vector of parameters to be estimated which reflect the implicit rental prices of the housing characteristics. The $\delta_{\mathrm{j}}$ and $\gamma_{\mathrm{j}}$ are city j specific intercepts and time trends to be estimated, $\lambda_{\mathrm{y}}$ are year specific effects, and $\varepsilon$ is a random error with mean zero but whose variance differs by SMSA and year. All of the model errors are clustered by SMSA-year, allowing the errors in rents within an SMSA in a year to be correlated with one another but not correlated with errors from other SMSAs or other years. If the variance of the regression error is assumed to be the same either among all SMSAs or among all years, and it is in fact, dissimilar, the standard errors of the regressions will be incorrect, and hypothesis tests will be unreliable. Clustering by both SMSA and year will allow the error variance to differ by both SMSA and year. In addition, inverse probability (of selection) weights are placed on the observations to make the sample data more representative of the population.

The null hypothesis is that the mega-event variables have no impact on residential rental values. That is, the coefficients in the vector $\alpha$ are all equal to zero. The alternative hypothesis is that at least one of the coefficients is different from zero. We will reject the null if the estimate of the impact of some mega-event is either improbably large or improbably small under the null hypothesis. We will also discuss the individual coefficients and, especially, the importance of a rental unit being within or outside of the central city of the SMSA.

\section{The Data}


The housing unit data used (both rental values and unit-specific characteristics) comes from the American Housing Survey AHS (national data, as opposed to metro). Descriptive statistics are reported in Table 1. The duration spans 13 years, from 1993 to 2005, inclusive. The regressions are estimated on three samples. The largest of the samples includes observations on 141 SMSAs (a complete listing is in the Appendix). The other two samples restrict attention to those SMSAs that are home to NFL, Major League Baseball, National Basketball Association, or National Hockey League franchises, which we call "big league cities", and those that hosted a Super Bowl between 1993 and 2005. In each sample, a little over $60 \%$ of the observations come from the central city of the SMSA as defined by the AHS.

The mean of the natural $\log$ of real rent is 6.1 to 6.2 in each of the samples. In dollars, the average monthly rents are 546 for the full sample, 565 for the big league cities sample, and 572 for the Super Bowl host cities. The average unit has 1.15 full bathrooms, 0.13 half baths, and 1.75 bedrooms. About $38 \%$ of the units in the full sample have central air conditioning, while $36 \%$ of the big league cities' units do and $44 \%$ of the Super Bowl host city units do. That split is not surprising since Super Bowl host cities tend to be warm weather locations, like Miami, New Orleans, and Los Angeles. Almost all are attached to the public sewer system; the vast majority $(75 \%$ in the full sample, $78 \%$ in the big league city sample, and over $90 \%$ in the Super Bowl host sample) are low rise units (less than three stories), and very few (less than about 2\%) have holes in the floor. Nearly half the rental units from Super Bowl host cities have garages, but only $30 \%$ of either the full or big league sample does. 
In the data, ten cities were 1994 World Cup venues. These cities were Boston, Chicago, Dallas, Detroit, Fort Worth, Los Angeles, New York, Orlando, San Jose, and Washington. Only two, Atlanta and Salt Lake City, held the Olympics; the 1996 Summer Games in Atlanta and the 2002 Winter Games in Salt Lake. The AHS national sample data is only collected in odd numbered years. Consequently, the best we can do is identify the World Cup and Olympic host observations in the year before and the year after the events. For some of the Super Bowl host cities that is also the best we can do. Moreover, if a city hosts the Super Bowl in an odd numbered year, we cannot identify observations for that city in the year prior to or the year after the game. Ten cities hosted the Super Bowl during the period from 1993 through 2005. The host cities are: Atlanta (1994, 2000), Houston (2004), Miami (1995, 1999), New Orleans (1997, 2002), Jacksonville (2005), San Diego (1998, 2003), Phoenix (1996), Tampa (2001), and Los Angeles (1993). Additionally, Minneapolis hosted the 1992 Super Bowl so observations from that city are identified in the 1993 data for the year after hosting the game. Detroit hosted the 2006 Super Bowl, so observations from that city in 2005 are associated with the year prior to hosting the game.

Clearly, the timing of the AHS and the events is not ideal. We would prefer to have data from a given city in the year before, the year of and the year following hosting an event. Such data would allow us to be more confident that we had captured any effects of the event on rents. For example, in the year prior to the event, rents may be bid up in anticipation of the tight housing market to come or as people attempt to acquire rental units that they can sublet during the event. In the year after the event, the market may contract, or the desirable attributes of hosting the event may make the city an 
attractive location for visitors or relocation helping to keep rents up or raise them further. Unfortunately, we cannot follow the rental market in a given SMSA from before the event. Our analysis identifies the cities it can in the year prior and the year subsequent to the event, but misses those cities in the year of the event. Other cities are identified in the year of the event, but we miss those cities in the years before and after. Consequently, our inferences are conditional on the assumption that the results for the two types of cities can be combined to piece together the story for any city from beginning to end.

\section{Results}

This section presents our findings from alternative samples of cities and from different specifications of the model. All models contain the same set of rental unit characteristics, city specific effects appropriate to the sample, and city specific time trends.

Table 2 reports the coefficient estimates from regressions on the full sample of SMSAs in our data. We focus only on the event coefficients in this table, reporting coefficients for the rental unit characteristics variables in Table A2 in the appendix. Each model in the table also includes city specific intercepts and city specific time trends. The first column, Model 1, contains results from the basic model, without interaction terms between the event variables and the central city dummy variable and without year specific effects. Model 2 adds central city interaction terms with each of the event variables; Model 3 extends Model 1 by introducing year dummies to the analysis, and Model 4 includes year dummies and the central city-event interactions. All models are estimated with clustering error terms by city and year. 
First consider the uninteracted event variables, the first nine rows of the column, across the four models. None of the Super Bowl variables is remotely statistically significant, indicating that a) there is no market anticipation of the benefits of the Super Bowl in the year prior to the event, b) there is no evidence of the rental market being tighter in the year of the Super Bowl, and c) after the Super Bowl there is no residual impact on the rental market. If hosting the Super Bowl affects the rental housing market in an SMSA, it is not apparent in these regressions. By contrast, the Olympic and World Cup variables are frequently individually significant.

For example, there are effects on the rental housing market in the year before and the year after hosting the Summer Olympics, the year prior to hosting the Winter Olympics, and both before and after hosting the World Cup. In Model 1, our results indicate that in the years before and after hosting the Summer Olympics, Atlanta saw its rents lower by $8 \%$ to $11 \%$. The significance of these results is sensitive to the inclusion of year and central city interactions, however. Consistent with the results in Coates and Gearhart (2008) for NASCAR races, the central city and non-central city are affected differently by the Summer Olympics. Looking at the results in Model 4, the non-central city housing units around Atlanta are not affected by the run up to the Summer Olympics and see an increase in rents after the games, while rental units in the city of Atlanta have lower rents both before and after hosting the games. Note that these effects are net of any general Atlanta effect and any Atlanta specific trend, as there are both a city specific intercept and city specific time trend in the model. Nonetheless, it may be that these results are specific to Atlanta rather than related to the Summer Olympics, as Atlanta is the only host of Summer Olympic Games in our data. 
The effect of hosting the Winter Olympic Games in Salt Lake City contrasts completely with the Atlanta results. Without central city interactions, neither the year before nor the year after the games is statistically different than other observations in our data. However, once the interaction terms are included, the evidence is that central city Salt Lake housing units have higher rents both before and after hosting the games, and rents outside Salt Lake City but still in the Salt Lake SMSA are lower than elsewhere prior to the games but no different afterwards.

The difference between the Atlanta and the Salt Lake City results is perhaps puzzling. Both cities built housing for the Olympic athletes which then was placed in the rental market once the Games were over. For example, in Salt Lake City, housing in the Olympic Village has been opened to 3,500 students. The New Georgia Encyclopedia says that in Atlanta, a public housing project (Techwood Homes) was replaced by a combination of apartments and dormitories. An increase in the supply of rental units would, all other things constant, result in lower rents after the Games. Our findings for Salt Lake City are clearly not consistent with this, suggesting that all other things were not constant. In Atlanta, the Centre on Housing Rights and Evictions argues, in Atlanta's Olympic Legacy: Background Paper (2007), that the Olympics served as a catalyst for gentrification of downtown Atlanta at the cost of losses of hundreds of rental units for low and moderate income individuals and families. Given the destruction of such a large number of units, we would expect rents to rise. However, many of these units were in public housing and it may be that individuals displaced from these units were too poor to effectively bid up rents on the existing or newly developed units. Alternatively, and consistent with our results, perhaps these displaced city dwellers moved out of the city 
but remained within the Atlanta SMSA. A large loss of demand in the city would force rents down, while the exodus to the suburbs would tend to bid up rents there. Moreover, if the gentrification produced an increase in the number of rental units for middle and upper middle class families that would cause the price of such units to come down.

Hosting of World Cup games may have had positive effects on the rental rates, though that finding is sensitive to the inclusion of the year specific dummy variables. In Models 1 and 2, both the year before the event and the year after the event, rents were higher in the host cities between $7 \%$ and $14 \%$. Each of these effects is statistically significant at the $1 \%$ level. Recall that the model includes city specific intercepts and time trends, so these effects on rents in the pre and post World Cup years are not simply due to omitting some characteristic common to the host cities. Of course, unlike the Super Bowl which is an annual event, the U.S. has only hosted the World Cup once, in 1994; therefore, the positive coefficients on the World Cup variables may simply be capturing strong housing markets nationwide. That these effects disappear once the year dummies are included supports the supposition that the World Cup results are year and not event driven.

The first panel of Table 5 summarizes the results of joint hypothesis tests on the full sample. The null hypotheses are that 1) all sports events variables have a zero coefficient (All Events), 2) all Super Bowl variables have a zero coefficient (Super Bowl only), 3) all Olympic variables have a zero coefficient (Olympics only), 4) all World Cup variables have a zero coefficient (World Cup only), and 5) all central city interaction terms have a zero coefficient (Interactions only). For the full sample, there are 18 different joint hypothesis tests reported, and in only six of them can the null not be 
rejected. In other words, in most cases the sporting event variables do not all carry zero coefficients. However, four of the six cases in which the null of no effect cannot be rejected are the Super Bowl only hypotheses. Put differently, every case in which the Super Bowl is the sole focus of the hypothesis, the evidence is that hosting the game is unrelated to rents in the SMSA. In each instance where the focus is on the Olympics, the tests reject the null of no impact. Likewise, the evidence is consistent that central city rents and non-central city rents are affected differently by hosting the events. The evidence also indicates that hosting the World Cup has no impact once the year dummies are included, but have an impact when they are not.

One possible objection to our results is that they are driven by the inclusion of large numbers of observations from small and moderately sized SMSAs, especially those that play host to none of the sporting events. We restrict the sample in two ways to assess this possibility. First, we focus on "big league" cities, those that were home to a franchise in one of the big four professional sport at any time during our sample. These results are reported in Table 3. Second, we focus only on those cities that actually hosted the Super Bowl between 1992 and 2006 (omitting Detroit whose inclusion has no little impact on the results) to evaluate the impact on rents of doing so, and report the results in Table 4 .

The big league cities sample produces results that are nearly identical to those from the full sample as a comparison of Tables 2 and 3 will attest. Each column in Table 3 corresponds to the same column in Table 2, including all the same regressors, The difference is that the big league cities sample of Table 3 utilizes about 17,000 fewer observations than the full sample. The lost observations come from SMSAs that hosted 
none of our events. The second panel of Table 5 reports the joint hypothesis tests on the big league cities sample, the results of which match perfectly with those of the full sample. Given the tight similarity between the full and big league cities samples, we discuss the latter no more, turning instead to the sample of Super Bowl host cities.

Restricting attention to Super Bowl host cities muddies the waters a bit on whether hosting the Super Bowl affects rents. Whereas the broader samples indicated no such impact, the more restrictive sample suggests that the central city areas may have lower rents in the year before and the year of the game, while the outlying areas may see a boost to rents in the year of the game. It is possible, however, that such findings are an artifact of omitted year specific effects as once those are included both the size and level of significance of the event variables decline. Nonetheless, in Model 12 which includes year dummies and central city interactions, the coefficients on the year of the game and the central city interaction with the year of the game are individually significant, at the 10 and 5\% levels respectively. These coefficients indicate that rental units within the central city have about $4 \%$ lower rents the year the game is in town, while non-central city units have $11 \%$ higher rents that year.

The bottom panel of Table 5 summarizes the results of joint hypothesis tests from the Super Bowl host cities sample. The null of no effect is clearly rejected at conventional significance levels for units within the central city (evidenced by the row for "All events" and "Interactions only"). Combining the central city and non-central city observations or focusing on the non-central city observations alone, the evidence is less supportive of an impact from hosting the Super Bowl. 
Summing up the Super Bowl case, the best that can be said is that hosting the Super Bowl has no effect, while the worst that can be said is that the Super Bowl raises rents in the suburbs but lowers them in the central city. One interpretation of these results is that the Super Bowl induces renters to move out of downtown, bidding up rents in the suburbs and bidding down rents in the city center. An alternative interpretation is if there are advertising or name recognition benefits that make an area more desirable after the Super Bowl, those benefits accrue to the suburbs but not to the central city area of the metropolis. Such an interpretation means that a city that wins a bid to host a Super Bowl may be providing a public service to its suburbs in a reverse Robin Hood sort of fashion.

Olympic host results are mixed. The problem is that only two cities hosted Olympics, so it is difficult to separate the hosting effects from the specific cities in specific years effects. The World Cup variables are less of a problem because there are more cities that hosted games. However, all of these games occurred in the same year. This means that it is not possible to distinguish between effects of hosting World Cup games and yearly rent shocks that are similar across several big cities.

The strongest result evident in Table 5 concerns the central city interaction terms. In each model which includes them, one must reject the null hypothesis that all the interaction terms carry a zero coefficient. This means that regardless of the event or events, and regardless of the sample of SMSAs from which observations are drawn, hosting the events has a different impact on rents in the suburbs than on rents in the central city. 


\section{Conclusions}

This paper examines the relationship between hosting mega-events such as the Super Bowl, Olympics, and World Cup and rental housing prices in host cities. If megaevents are amenities for local residents, then rental housing prices can serve as a proxy for estimating residents' willingness to pay for these amenities. An analysis of rental prices in a panel of American cities from 1993-2005 fails to find a consistent impact of mega-events on rental prices. When controls are placed on the regression models to account for nationwide annual fluctuations in rental prices, mega-events generally exhibit little impact on rental prices in cities as a whole and are as likely to reduce rental prices as increase them. Somewhat stronger evidence exists, however, that mega-events affect rental prices outside of the center city in a fundamentally different manner than in the city core.

If this analysis had uncovered a consistent pattern of higher rental prices associated with mega-events, such evidence would provide a strong justification for subsidizing this type of event. Higher rental prices may capture a willingness to pay to live in a city that provides these types of entertainment for its citizens that is perhaps not captured by more direct explorations of the economic impact of mega-events. However, the various model specifications show that rental prices are as likely to fall as they are to raise during mega-events suggesting that renters do not display a preference for living in cities hosting the Super Bowl, Olympics, or World Cup, and may, in fact, display a preference to not live in cities disrupted by these events. Furthermore, in the case of the Super Bowl and Summer Olympics, renters show an increased desire to live outside the center city at the expense of rental rates in the central area although the reverse appears to 
be true for the Winter Olympics. Taken as a whole, an analysis of housing rental prices does not support the conclusion that local residents place a large value on the honor of hosting these events. 


\section{References}

Ahlfeldt, Gabriel and Wolfgang Maennig. 2007. Impact of Sports Arenas on Land Values: Evidence from Berlin. International Association of Sports Economists, Working Paper 07-03, forthcoming in Annals of Regional Science.

Arizona Super Bowl Host Committee. 2008. Super Bowl FAQs. http://azsuperbowl.com/super_bowl_faqs.aspx, accessed September 15, 2008.

Atkinson, Giles, Susana Mourato, Stefan Szymanski, and Ece Ozdemiroglu. 2008. Are We Willing to Pay Enough to 'Back the Bid'?: Valuing the Intangible Impacts of London's Bid to Host the 2012 Summer Olympic Games. Urban Studies, Vol. $45: 2,419-444$.

Baade, Robert A., Robert Baumann, and Victor A. Matheson. 2008. Selling the Game: Estimating the Economic Impact of Professional Sports through Taxable Sales. Southern Economic Journal, Vol. 74:3, 794-810.

Baade, Robert and Victor Matheson. 2001. Home Run or Wild Pitch? Assessing the Economic Impact of Major League Baseball's All-Star Game. Journal of Sports Economics, 2:4, 307-327.

Baade, Robert A. and Victor A. Matheson. 2004. The Quest for the Cup: Assessing the Economic Impact of the World Cup. Regional Studies, Vol. 38:4, 343-354.

Baade, Robert A. and Victor A. Matheson. 2006. Padding Required: Assessing the Economic Impact of the Super Bowl. European Sports Management Quarterly, Vol. 6:4, 353-374. 
Baumann, Robert, Victor A. Matheson, and Chihiro Muroi. 2009. Bowling in Hawaii: Examining the Effectiveness of Sports-Based Tourism Strategies. Journal of Sports Economics, Vol. 10:1, (February 2009), 107-123.

Baker, Greg. 2008. Beijing's welcome is mix of pride, spies and suspicion. USA Today, August 5, 2008.

Berlin, Peter. 2008. London's Countdown to 2012 Begins With Questions. New York Times, August 24, 2008.

Boyle, Melissa A. and Katherine A. Kiel. 2001. A Survey of House Price Hedonic Studies of the Impact of Environmental Externalities. Journal of Real Estate Literature, Vol. 9:2, 117-144.

Carlino, Gerald and N. Edward Coulson. 2004. Compensating differentials and the social benefits of the NFL. Journal of Urban Economics, 56:1, 25-50.

Centre on Housing Rights and Evictions. 2007. Atlanta's Olympic Legacy: Background Paper.

Coates, Dennis. 2006. The Tax Benefits of Hosting the Super Bowl and the MLB AllStar Game: The Houston Experience. International Journal of Sport Finance, 1:4, 239-252.

Coates, Dennis and Craig A. Depken, II. 2006. Mega-Events: Is the Texas-Baylor game to Waco what the Super Bowl is to Houston? International Association of Sports Economists, Working Paper 06-06.

Coates, Dennis and David Gearhart. 2008. NASCAR as a Public Good. International Journal of Sport Finance, 3:1, 42-57. 
Coates, Dennis and Brad R. Humphreys. 2002. The Economic Impact of Post-Season Play in Professional Sports. Journal of Sports Economics, 3, 291-299.

Coates, Dennis, Brad R. Humphreys, and Andrew Zimbalist. 2006. Compensating differentials and the social benefits of the NFL: A comment. Journal of Urban Economics, Vol. 60:1, 124-131.

Feng, Xia and Brad R. Humphreys. 2008. Assessing the Economic Impact of Sports Facilities on Residential Property Values: A Spatial Hedonic Approach. International Association of Sports Economists, Working Paper 08-12.

Groothuis, Peter A., Bruce K. Johnson, and John C. Whitehead (2004). Public Funding of Professional Sports Stadiums: Public Choice or Civic Pride? Eastern Economic Journal, Vol. 30:4, 515-526.

Hagn, Florian and Wolfgang Maennig. 2007a. Labour Market Effects of the 2006 Soccer World Cup in Germany. International Association of Sports Economists Working Paper Series, No. 07-16. Forthcoming in Applied Economics.

Hagn, Florian and Wolfgang Maennig. 2007b. Short-term to long-term employment effects of the Football World Cup 1974 in Germany. International Association of Sports Economists Working Paper Series, No. 07-21. Forthcoming in Labor Economics.

Hawaii Tourism Authority. 2007. HTA 2007 Annual Report to the Hawaii State Legislature. www.hawaiitourismauthority.org.

Jasmand, Stephanie and Wolfgang Maennig. 2007. Regional Income and Employment Effects of the 1972 Munich Olympic Summer Games. International Association 
of Sports Economists Working Paper Series, No. 07-12. Forthcoming in Regional Studies.

Johnson, Bruce K., Peter A. Groothuis, John C. Whitehead. 2001. The Value of Public Goods Generated by a Major League Sports Team: The CVM Approach. Journal of Sports Economics, Vol. 2:1, 6-21.

Johnson, Bruce K., Michael J. Mondello, and John C. Whitehead, John C. 2006. Contingent Valuation of Sports: Temporal Embedding and Ordering Effects Journal of Sports Economics, Vol. 7:3, 267-288.

Maennig, Wolfgang. 2007. One year later: A re-appraisal of the economics of the 2006 soccer World Cup. International Association of Sports Economists Working Paper Series, No. 07-25.

Matheson, Victor A. 2008. Mega-Events: The Effect of the World's Biggest Sporting Events on Local, Regional, and National Economies. The Business of Sports, Vol. 1, Dennis Howard and Brad Humphreys, eds., (Westport, CT: Praeger Publishers), 81-99.

Meeks, Brock. 2004. Record expense, security plans set for Olympics. MSNBC, http://www.msnbc.msn.com/id/5490540, posted July 20, 2004, accessed September 15, 2008.

New Georgia Encyclopedia. Olympic Games in 1996. http://www.georgiaencyclopedia.org/nge/Article.jsp?id=h-2042, accessed 1/9/09. Porter, Philip. 1999. Mega-Sports Events as Municipal Investments: A Critique of Impact Analysis. In Fizel, J., Gustafson, E. and Hadley, L. Sports Economics: Current Research. Westport, CT: Praeger Press, 61-74. 
Ritchie, J.R. Brent and Brian H. Smith (1991). The Impact Of A Mega-Event On Host Region Awareness: A Longitudinal Study, Journal of Travel Research, 30:1, 310.

Siegfried, John and Andrew Zimbalist. 2000. The Economics of Sports Facilities and Their Communities, Journal of Economic Perspectives, 14, 95-114.

Teigland, Jon (1999). Mega-events and impacts on tourism; the predictions and realities of the Lillehammer Olympics , Impact Assessment and Project Appraisal, 17:4, $305-317$.

Tu, Charles C. 2005. How Does a New Sports Stadium Affect Housing Values? The Case of FedEx Field. Land Economics, 81:3, 379-395.

Walton, Harry, Alberto Longo, and Peter Dawson 2008. A Contingent Valuation of the 2012 London Olympic Games: A Regional Perspective. Journal of Sports Economics, Vol. 9:3, 304-317. 
Table 1: Descriptive Statistics

\begin{tabular}{lrrrrrr} 
& \multicolumn{2}{l}{ Full Sample } & \multicolumn{2}{c}{ Big League Cities } & \multicolumn{2}{l}{ Super Bowl Hosts } \\
Variable & \multicolumn{1}{c}{ Mean } & Std.Dev. & Mean & Std.Dev. & \multicolumn{1}{l}{ Mean } & Std.Dev. \\
Log of real rent & 6.134 & 0.736 & 6.169 & 0.734 & 6.222 & 0.623 \\
Host Super Bowl & 0.021 & 0.144 & 0.028 & 0.166 & 0.090 & 0.287 \\
Hosted SB last year & 0.015 & 0.122 & 0.020 & 0.141 & 0.065 & 0.247 \\
Host SB next year & 0.016 & 0.126 & 0.022 & 0.146 & 0.057 & 0.232 \\
Host Summer Olympics & & & & & & \\
next year & 0.002 & 0.047 & 0.003 & 0.055 & 0.001 & 0.097 \\
Hosted Summer Olympics & & & & & & \\
last year & 0.002 & 0.042 & 0.002 & 0.049 & 0.001 & 0.088 \\
Host Winter Olympics next & & & & & & \\
year & 0.001 & 0.025 & 0.001 & 0.029 & $\mathrm{Na}$ & \\
Hosted Winter Olympics & & & & & & \\
last year & 0.001 & 0.027 & 0.001 & 0.031 & $\mathrm{Na}$ & \\
Host World Cup next year & 0.046 & 0.209 & 0.060 & 0.237 & 0.044 & 0.205 \\
Hosted World Cup last year & 0.072 & 0.258 & 0.095 & 0.293 & 0.106 & 0.308 \\
Central Air Conditioning & 0.381 & 0.486 & 0.358 & 0.479 & 0.432 & 0.495 \\
Bathrooms & 1.148 & 0.430 & 1.144 & 0.426 & 1.218 & 0.475 \\
Bedrooms & 1.787 & 0.900 & 1.760 & 0.897 & 1.726 & 0.867 \\
Detached unit & 0.145 & 0.352 & 0.129 & 0.335 & 0.180 & 0.385 \\
Garage & 0.304 & 0.460 & 0.313 & 0.464 & 0.478 & 0.500 \\
Half bathrooms & 0.126 & 0.363 & 0.126 & 0.360 & 0.132 & 0.356 \\
Holes in the floor & 0.020 & 0.139 & 0.021 & 0.143 & 0.017 & 0.129 \\
Highrise & 0.063 & 0.244 & 0.077 & 0.266 & 0.021 & 0.142 \\
Lowrise & 0.789 & 0.408 & 0.756 & 0.429 & 0.910 & 0.286 \\
Public sewer & 0.986 & 0.118 & 0.990 & 0.101 & 0.989 & 0.104 \\
Age & 41.076 & 23.756 & 42.003 & 23.678 & 34.537 & 19.546 \\
Central City & 0.627 & 0.484 & 0.624 & 0.484 & 0.602 & 0.489 \\
Observations & 67180 & & 49999 & & 15681 &
\end{tabular}


Table 2: Full Sample Regression Results

\begin{tabular}{|c|c|c|c|c|}
\hline VARIABLES & $\begin{array}{c}(1) \\
\text { Model } 1\end{array}$ & $\begin{array}{c}(2) \\
\text { Model } 2\end{array}$ & $\begin{array}{c}(3) \\
\text { Model } 3\end{array}$ & $\begin{array}{c}(4) \\
\text { Model } 4\end{array}$ \\
\hline \multirow[t]{2}{*}{ superbowl } & 0.016 & 0.002 & 0.018 & 0.004 \\
\hline & $(0.469)$ & $(0.933)$ & $(0.401)$ & $(0.899)$ \\
\hline \multirow[t]{2}{*}{ sbplus1 } & -0.011 & -0.012 & 0.004 & -0.009 \\
\hline & $(0.647)$ & $(0.730)$ & $(0.876)$ & $(0.801)$ \\
\hline \multirow[t]{2}{*}{ sbminus1 } & -0.012 & -0.036 & 0.009 & -0.010 \\
\hline & $(0.696)$ & $(0.536)$ & $(0.675)$ & $(0.848)$ \\
\hline \multirow[t]{2}{*}{ presumoly } & $-0.078 *$ & -0.060 & $-0.087 * *$ & -0.056 \\
\hline & $(0.055)$ & $(0.266)$ & $(0.019)$ & $(0.271)$ \\
\hline \multirow[t]{2}{*}{ postsumoly } & $-0.111 * * *$ & 0.003 & -0.024 & $0.091 * *$ \\
\hline & $(0.001)$ & $(0.931)$ & $(0.403)$ & $(0.011)$ \\
\hline \multirow[t]{2}{*}{ prewintoly } & -0.000 & $-0.093 * * *$ & -0.013 & $-0.106 * *$ \\
\hline & $(0.995)$ & $(0.008)$ & $(0.794)$ & $(0.029)$ \\
\hline \multirow[t]{2}{*}{ postwintoly } & 0.067 & -0.006 & 0.055 & -0.018 \\
\hline & $(0.141)$ & $(0.887)$ & $(0.365)$ & $(0.768)$ \\
\hline \multirow[t]{2}{*}{ prewc } & $0.119 * * *$ & $0.141 * * *$ & 0.024 & 0.046 \\
\hline & $(0.000)$ & $(0.000)$ & $(0.348)$ & $(0.193)$ \\
\hline \multirow[t]{2}{*}{ postwc } & $0.105 * * *$ & $0.076 * * *$ & 0.022 & -0.008 \\
\hline & $(0.000)$ & $(0.003)$ & $(0.333)$ & $(0.767)$ \\
\hline \multirow[t]{2}{*}{ sbcencity } & & 0.020 & & 0.021 \\
\hline & & $(0.553)$ & & $(0.535)$ \\
\hline \multirow[t]{2}{*}{ sbpcencity } & & 0.002 & & 0.023 \\
\hline & & $(0.960)$ & & $(0.635)$ \\
\hline \multirow[t]{2}{*}{ sbmcencity } & & 0.039 & & 0.033 \\
\hline & & $(0.617)$ & & $(0.681)$ \\
\hline \multirow[t]{2}{*}{ presumcent } & & $-0.088^{*}$ & & $-0.108 * *$ \\
\hline & & $(0.071)$ & & $(0.022)$ \\
\hline \multirow[t]{2}{*}{ prewincent } & & $0.237 * * *$ & & $0.237 * * *$ \\
\hline & & $(0.000)$ & & $(0.000)$ \\
\hline \multirow[t]{2}{*}{ postsumcent } & & $-0.259 * * *$ & & $-0.259 * * *$ \\
\hline & & $(0.000)$ & & $(0.000)$ \\
\hline \multirow[t]{2}{*}{ postwintcent } & & $0.186 * * *$ & & $0.186^{* * *}$ \\
\hline & & $(0.000)$ & & $(0.000)$ \\
\hline \multirow[t]{2}{*}{ prewccencity } & & -0.031 & & -0.030 \\
\hline & & $(0.405)$ & & $(0.417)$ \\
\hline \multirow[t]{2}{*}{ postwccencity } & & 0.044 & & 0.044 \\
\hline & & $(0.181)$ & & $(0.172)$ \\
\hline Observations & 67180 & 67180 & 67180 & 67180 \\
\hline R-squared & 0.988 & 0.988 & 0.988 & 0.988 \\
\hline
\end{tabular}


Table 3: Big League Cities Regression Results

(1)

\begin{tabular}{|c|c|c|c|c|}
\hline VARIABLES & Model 5 & Model 6 & Model 7 & Model 8 \\
\hline superbowl & $\begin{array}{c}0.017 \\
(0.436)\end{array}$ & $\begin{array}{c}0.001 \\
(0.964)\end{array}$ & $\begin{array}{c}0.018 \\
(0.403)\end{array}$ & $\begin{array}{c}0.001 \\
(0.961)\end{array}$ \\
\hline sbplus 1 & $\begin{array}{l}-0.011 \\
(0.639)\end{array}$ & $\begin{array}{l}-0.014 \\
(0.702)\end{array}$ & $\begin{array}{c}0.005 \\
(0.856)\end{array}$ & $\begin{array}{l}-0.010 \\
(0.761)\end{array}$ \\
\hline sbminus1 & $\begin{array}{c}-0.013 \\
(0.670)\end{array}$ & $\begin{array}{l}-0.038 \\
(0.507)\end{array}$ & $\begin{array}{c}0.010 \\
(0.661)\end{array}$ & $\begin{array}{l}-0.010 \\
(0.845)\end{array}$ \\
\hline presumoly & $\begin{array}{c}-0.079 * * \\
(0.049)\end{array}$ & $\begin{array}{l}-0.062 \\
(0.253)\end{array}$ & $\begin{array}{c}-0.082 * * \\
(0.033)\end{array}$ & $\begin{array}{c}-0.050 \\
(0.342)\end{array}$ \\
\hline postsumoly & $\begin{array}{c}-0.107 * * * \\
(0.001)\end{array}$ & $\begin{array}{c}0.004 \\
(0.909)\end{array}$ & $\begin{array}{c}-0.016 \\
(0.621)\end{array}$ & $\begin{array}{c}0.098 * * * \\
(0.010)\end{array}$ \\
\hline prewintoly & $\begin{array}{c}-0.003 \\
(0.929)\end{array}$ & $\begin{array}{c}-0.098 * * * \\
(0.007)\end{array}$ & $\begin{array}{l}-0.017 \\
(0.724)\end{array}$ & $\begin{array}{c}-0.112 * * \\
(0.024)\end{array}$ \\
\hline postwintoly & $\begin{array}{c}0.067 \\
(0.145)\end{array}$ & $\begin{array}{c}-0.007 \\
(0.870)\end{array}$ & $\begin{array}{c}0.047 \\
(0.451)\end{array}$ & $\begin{array}{l}-0.027 \\
(0.665)\end{array}$ \\
\hline prewc & $\begin{array}{c}0.122 * * * \\
(0.000)\end{array}$ & $\begin{array}{c}0.148 * * * \\
(0.000)\end{array}$ & $\begin{array}{c}0.021 \\
(0.485)\end{array}$ & $\begin{array}{c}0.046 \\
(0.237)\end{array}$ \\
\hline postwc & $\begin{array}{c}0.112 * * * \\
(0.000)\end{array}$ & $\begin{array}{c}0.087 * * * \\
(0.000)\end{array}$ & $\begin{array}{c}0.030 \\
(0.226)\end{array}$ & $\begin{array}{c}0.005 \\
(0.857)\end{array}$ \\
\hline sbcencity & & $\begin{array}{c}0.024 \\
(0.501)\end{array}$ & & $\begin{array}{c}0.024 \\
(0.480)\end{array}$ \\
\hline sbpcencity & & $\begin{array}{c}0.005 \\
(0.925)\end{array}$ & & $\begin{array}{c}0.027 \\
(0.578)\end{array}$ \\
\hline sbmcencity & & $\begin{array}{c}0.042 \\
(0.595)\end{array}$ & & $\begin{array}{c}0.034 \\
(0.669)\end{array}$ \\
\hline presumcent & & $\begin{array}{c}-0.087^{*} \\
(0.082)\end{array}$ & & $\begin{array}{c}-0.109 * * \\
(0.025)\end{array}$ \\
\hline prewincent & & $\begin{array}{c}0.241 * * * \\
(0.000)\end{array}$ & & $\begin{array}{c}0.241^{* * *} \\
(0.000)\end{array}$ \\
\hline postsumcent & & $\begin{array}{c}-0.256^{* * *} \\
(0.000)\end{array}$ & & $\begin{array}{c}-0.256^{* * *} * \\
(0.000)\end{array}$ \\
\hline postwintcent & & $\begin{array}{c}0.188 * * * \\
(0.000)\end{array}$ & & $\begin{array}{c}0.188 * * * \\
(0.000)\end{array}$ \\
\hline prewccencity & & $\begin{array}{l}-0.037 \\
(0.328)\end{array}$ & & $\begin{array}{l}-0.036 \\
(0.337)\end{array}$ \\
\hline postwccencity & & $\begin{array}{c}0.036 \\
(0.266)\end{array}$ & & $\begin{array}{c}0.037 \\
(0.254)\end{array}$ \\
\hline Observations & 49999 & 49999 & 49999 & 49999 \\
\hline R-squared & 0.988 & 0.988 & 0.988 & 0.988 \\
\hline
\end{tabular}

All models include city specific dummy variables and city specific time trends. 
Table 4: Super Bowl Host Cities Regression Results

(1)

(2)

(3)

(4)

\begin{tabular}{lcccc} 
VARIABLES & Model 9 & Model 10 & Model 11 & Model 12 \\
\hline superbowl & 0.041 & $0.181^{* * *}$ & 0.024 & $0.110^{*}$ \\
& $(0.398)$ & $(0.007)$ & $(0.680)$ & $(0.099)$ \\
sbplus1 & 0.122 & $0.301^{*}$ & -0.142 & -0.208 \\
& $(0.334)$ & $(0.093)$ & $(0.133)$ & $(0.219)$ \\
sbminus1 & 0.031 & 0.143 & $-0.094^{*}$ & -0.018 \\
& $(0.618)$ & $(0.141)$ & $(0.072)$ & $(0.835)$ \\
sbcencity & & $-0.243^{* * *}$ & & $-0.150^{* *}$ \\
& & $(0.004)$ & $(0.035)$ \\
sbpcencity & & $-0.355^{* *}$ & & 0.130 \\
& & $(0.031)$ & & $-0.439)$ \\
sbmcencity & & -0.201 & & -0.122 \\
& & $(0.119)$ & & 15681 \\
Observations & 15681 & 15681 & 15681 & 0.986 \\
R-squared & 0.984 & 0.984 & 0.986 & \\
& Robust $\mathrm{p}$ values in parentheses &
\end{tabular}

All models include city specific dummy variables and city specific time trends. 
Table 5: Joint Hypothesis Tests

\begin{tabular}{lllr}
\multicolumn{2}{c}{ No Central City Interactions } & \multicolumn{2}{c}{ Central City Interactions } \\
No Year & Year & No Year & \\
Effects & Effects & Effects & Year Effects
\end{tabular}

Null: Coefficients equal

zero

All Events

Reject

Full Sample

Super Bowl Only

Not Reject

Reject

Reject

Reject

Olympics Only

Reject

Not Reject

Not Reject

Not Reject

World Cup Only

Reject

Reject (5\%) Reject

Reject

Interactions Only

Not Reject Reject

Not Reject

Reject

Reject

Big League Cities

$\begin{array}{llll}\text { All Events } & \text { Reject } & \text { Reject } & \text { Reject }\end{array}$

Super Bowl Only

Not Reject

Not Reject Not Reject

Not Reject

Olympics Only

Reject

Reject (5\%) Reject

Reject

World Cup Only

Reject

Not Reject Reject

Not Reject

Interactions Only

Reject

Reject

Super Bowl Hosts

All Events

Reject (5\%)

Reject

(10\%)

Super Bowl Only

Not Reject

Not Reject

Reject (5\%)

Not Reject

Interactions Only

Reject

Reject (5\%)

Rejections at the $1 \%$ level if not otherwise noted. 
Appendix

Table A1: Sample SMSAs

\begin{tabular}{|c|c|c|c|c|}
\hline Akron & Colorado Springs & Houston $^{\mathrm{NS}}$ & Montgomery & San Antonio $^{\mathrm{N}}$ \\
\hline Albany & Columbia & Indianapolis $^{\mathrm{N}}$ & Nashville $^{\mathrm{N}}$ & San Diego ${ }^{\text {NS }}$ \\
\hline Albuquerque & Columbus $^{\mathrm{N}}$ & Jackson & Nassau & San Francisco ${ }^{N}$ \\
\hline Allentown & Corpus Christi & Jacksonville $^{\mathrm{NS}}$ & New Haven & San Jose ${ }^{N W}$ \\
\hline Alton & Dallas $^{\mathrm{NW}}$ & Jersey City & New Orleans ${ }^{\mathrm{NS}}$ & Santa Barbara \\
\hline Anaheim $^{\mathrm{N}}$ & Davenport & Johnson City & New York ${ }^{\mathrm{NW}}$ & Santa Rosa \\
\hline Appleton & Daytona Beach & Kansas City $^{\mathrm{N}}$ & Newark $^{\mathrm{N}}$ & Sarasota \\
\hline Atlanta ${ }^{\mathrm{NSWO}}$ & Denver $^{\mathrm{N}}$ & Knoxville & Norfolk & Scranton \\
\hline Atlantic City & Desmoines & Lake County & $\begin{array}{l}\text { Oakland }^{\mathrm{N}} \\
\text { Oklahoma }\end{array}$ & Seattle $^{N}$ \\
\hline Augusta & Detroit $^{\text {NWS }}$ & Lakeland & City $^{N}$ & Shreveport \\
\hline Aurora & Duluth & Lancaster & Omaha & Spokane \\
\hline Austin & East St Louis & Lansing & Orlando $^{\mathrm{NW}}$ & Springfield \\
\hline Bakersfield & El Paso & Las Vegas & Oxnard & Stamford \\
\hline Baltimore $^{N}$ & Erie & Lawrence & Pensacola & Stockton \\
\hline Batonrouge & Eugene & Lexington & Peoria & Syracuse \\
\hline Beaumont & Evansville & Little Rock & Philadelphia $^{\mathrm{N}}$ & Tacoma \\
\hline Beaver & Flint & Los Angeles ${ }^{\mathrm{NWS}}$ & Phoenix $^{\text {NS }}$ & Tampa $^{\mathrm{NS}}$ \\
\hline $\begin{array}{l}\text { Bergen- } \\
\text { Passaic }\end{array}$ & Ft Lauderdale & Madison & Pittsburgh $^{\mathrm{N}}$ & Toledo \\
\hline Birmingham & Ft Myers & McAllen & Providence & Trenton \\
\hline Boston $^{\mathrm{NW}}$ & Ft Wayne & Melbourne & Raleigh $^{\mathrm{N}}$ & Tucson \\
\hline Boulder & Ft Worth ${ }^{\mathrm{W}}$ & Memphis $^{\mathrm{N}}$ & Riverside & Tulsa \\
\hline Bridgeport & Fresno & $\mathrm{Miami}^{\mathrm{NS}}$ & Rochester & Utica \\
\hline Canton & Gary & Middlesex & Rockford & Vallejo \\
\hline Charleston & Grand Rapids & Milwaukee $^{\mathrm{N}}$ & Sacramento $^{\mathrm{N}}$ & Washington $^{\mathrm{N}}$ \\
\hline Chattanooga & Greensboro & Minneapolis $^{\text {NS }}$ & St. Louis ${ }^{\mathrm{N}}$ & $\begin{array}{l}\text { Waterbury } \\
\text { West Palm }\end{array}$ \\
\hline Chicago $^{\mathrm{NW}}$ & Greenville & Mobile & Salem & Beach \\
\hline Cincinnati $^{\mathrm{N}}$ & Hartford $^{\mathrm{N}}$ & Modesto & Salinas & Wichita \\
\hline Cleveland $^{\mathrm{N}}$ & Honolulu & Monmouth & Salt Lake City ${ }^{\mathrm{O}}$ & $\begin{array}{l}\text { Worcester } \\
\text { Youngstown }\end{array}$ \\
\hline \multicolumn{5}{|c|}{${ }^{\mathrm{N}}$ denotes Big League city } \\
\hline \multicolumn{5}{|c|}{${ }^{\mathrm{S}}$ denotes Super Bowl host } \\
\hline \multicolumn{5}{|c|}{${ }^{\mathrm{W}}$ denotes World Cup host } \\
\hline
\end{tabular}


Table A5: Big League Cities Housing Characteristics Regression Results

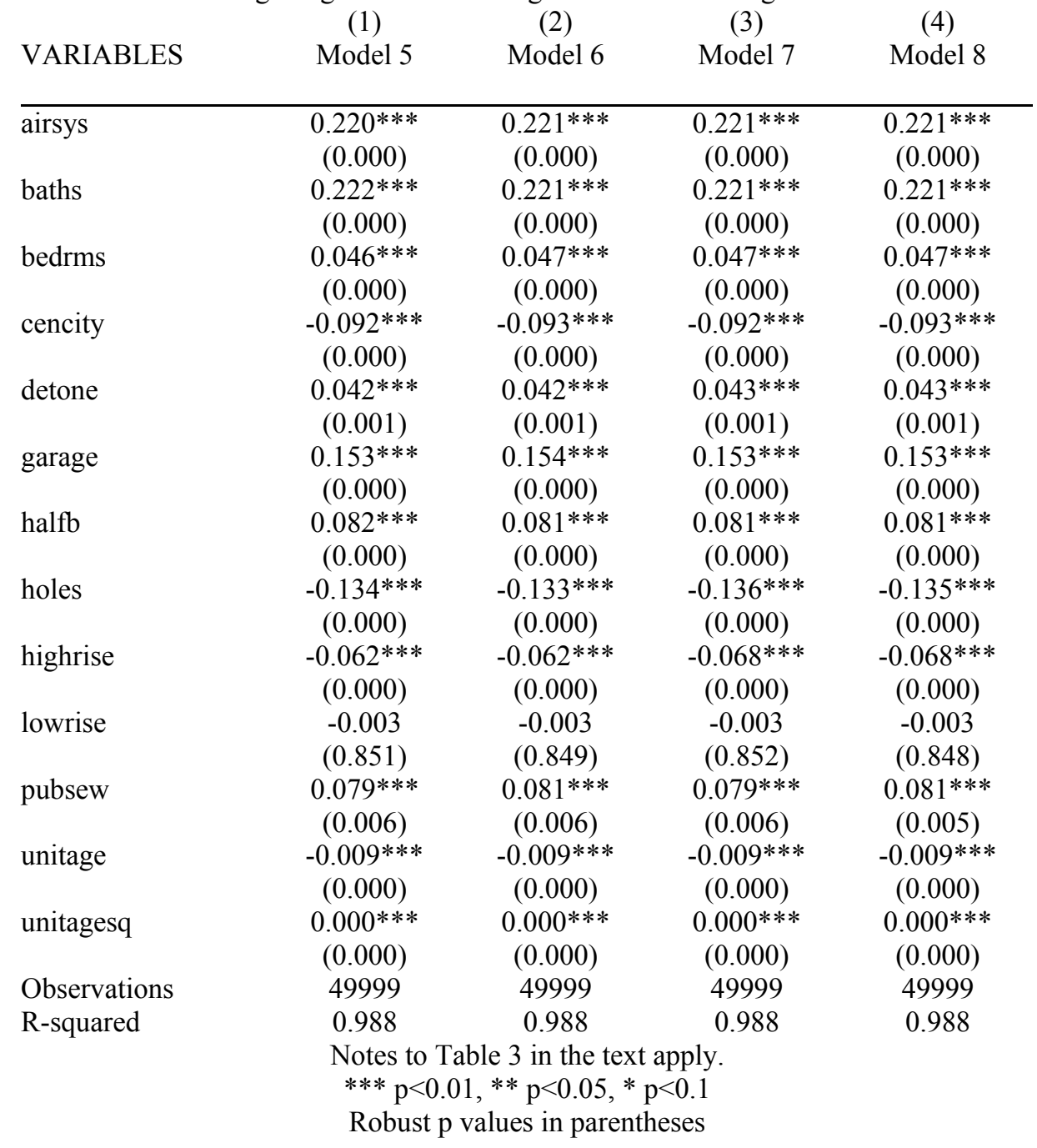


Table A7: Super Bowl Host Cities Housing Characteristics Regression Results

(1) (2) (3)

(4)

\begin{tabular}{|c|c|c|c|c|}
\hline VARIABLES & Model 9 & Model 10 & Model 11 & Model 12 \\
\hline \multirow[t]{2}{*}{ cencity } & 0.018 & $0.082 * * *$ & 0.001 & 0.019 \\
\hline & $(0.321)$ & $(0.004)$ & $(0.954)$ & $(0.513)$ \\
\hline \multirow[t]{2}{*}{ airsys } & $0.330 * * *$ & $0.330 * * *$ & $0.310 * * *$ & $0.308 * * *$ \\
\hline & $(0.000)$ & $(0.000)$ & $(0.000)$ & $(0.000)$ \\
\hline \multirow[t]{2}{*}{ baths } & $0.454 * * *$ & $0.446 * * *$ & $0.390 * * *$ & $0.390 * * *$ \\
\hline & $(0.000)$ & $(0.000)$ & $(0.000)$ & $(0.000)$ \\
\hline \multirow[t]{2}{*}{ bedrms } & $0.121 * * *$ & $0.122 * * *$ & $0.114 * * *$ & $0.114^{*} * *$ \\
\hline & $(0.000)$ & $(0.000)$ & $(0.000)$ & $(0.000)$ \\
\hline \multirow[t]{2}{*}{ detone } & $-0.093 * * *$ & $-0.091 * * *$ & $-0.069 * *$ & $-0.068 * *$ \\
\hline & $(0.002)$ & $(0.002)$ & $(0.020)$ & $(0.022)$ \\
\hline \multirow[t]{2}{*}{ garage } & $0.241 * * *$ & $0.246 * * *$ & $0.220 * * *$ & $0.219 * * *$ \\
\hline & $(0.000)$ & $(0.000)$ & $(0.000)$ & $(0.000)$ \\
\hline \multirow[t]{2}{*}{ halfb } & $0.134 * * *$ & $0.133 * * *$ & $0.133 * * *$ & $0.133 * * *$ \\
\hline & $(0.000)$ & $(0.000)$ & $(0.000)$ & $(0.000)$ \\
\hline \multirow[t]{2}{*}{ holes } & $-0.166^{*}$ & $-0.166^{*}$ & $-0.167 * *$ & $-0.170 * *$ \\
\hline & $(0.056)$ & $(0.055)$ & $(0.046)$ & $(0.042)$ \\
\hline \multirow[t]{2}{*}{ highrise } & $0.475 * * *$ & $0.461 * * *$ & $0.398 * * *$ & $0.396 * * *$ \\
\hline & $(0.000)$ & $(0.000)$ & $(0.000)$ & $(0.000)$ \\
\hline \multirow[t]{2}{*}{ lowrise } & $0.434 * * *$ & $0.425 * * *$ & $0.346 * * *$ & $0.346 * * *$ \\
\hline & $(0.000)$ & $(0.000)$ & $(0.002)$ & $(0.001)$ \\
\hline \multirow[t]{2}{*}{ pubsew } & $3.800 * * *$ & $3.762 * * *$ & $2.902 * * *$ & $2.893 * * *$ \\
\hline & $(0.000)$ & $(0.000)$ & $(0.000)$ & $(0.000)$ \\
\hline \multirow[t]{2}{*}{ unitage } & $0.021 * * *$ & $0.022 * * *$ & $0.015 * * *$ & $0.014 * * *$ \\
\hline & $(0.000)$ & $(0.000)$ & $(0.003)$ & $(0.004)$ \\
\hline \multirow[t]{2}{*}{ unitagesq } & $-0.000 * * *$ & $-0.000 * * *$ & $-0.000 * * *$ & $-0.000 * * *$ \\
\hline & $(0.000)$ & $(0.000)$ & $(0.007)$ & $(0.008)$ \\
\hline Observations & 15681 & 15681 & 15681 & 15681 \\
\hline R-squared & 0.984 & 0.984 & 0.986 & 0.986 \\
\hline
\end{tabular}

Notes to Table 4 in the text apply. 